\title{
Fatty Acid Profile of Hepatopancreas and Oocyte of Tiger Shrimp, Penaeus monodon, Fed Modified-commercial Diet by Supplementing Vitamin $\mathrm{C}$ and $\mathrm{E}$
}

\author{
Usman, Kamaruddin, Asda Laining, and Ike Trismawanti \\ Research Institute for Coastal Aquaculture and Fisheries Extension (RICAFE) \\ Jl. Makmur Dg. Sitakka No. 129, Maros, INDONESIA \\ E-mail: siganus007@yahoo.com
}

Received: 12 December 2018; Accepted: 15 March 2019

\begin{abstract}
Usman, Kamaruddin, Asda Laining, and Ike Trismawanti. 2019. Fatty Acid Profile of Hepatopancreas and Oocyte of Tiger Shrimp, Penaeus monodon, Fed Modified-commercial Diet by Supplementing Vitamin $C$ and E. Aquacultura Indonesiana, 20 (1): 15-23. The aim of this study was to evaluate the effect of vitamin $\mathrm{C}$ and $\mathrm{E}$ supplementation in modified-commercial diet on the fatty acids profile of hepatopancreas and oocyte of tiger shrimp, Penaeus monodon. The experimental treatments were: modifiedcommercial diet by supplementing vitamin C $(500 \mathrm{mg} / \mathrm{kg})$ and $\mathrm{E}(300 \mathrm{mg} / \mathrm{kg})$ (PS), and modified-commercial diet without vitamins supplementation (PK). Cultured tiger shrimp with initial weight of 43.1 $\pm 5.1 \mathrm{~g} / \mathrm{ind}$ for females and $41.9 \pm 4.4 \mathrm{~g}$ for males (rasio 4:6) were cultured in two of $1000 \mathrm{~m}^{2}$ concrete ponds with a density of $100 \mathrm{shrimp} /$ pond. They were fed the test diet at rate of $3 \%$ biomass/day for three months in pond, then they were transferred to concrete tanks for oocyte maturation evaluation. The shrimp reaching oocyte development stage III were dissected and sampled for hepatopancreas and oocytes for analysis of fatty acid profile. The results showed that the hepatopancreas and oocyte fatty acids contents were higher in the tiger shrimp fed PS compared to the tiger shrimp fed PK. The poly unsaturated fatty acid (PUFA) especially for arachidonic, docosahexaenoic, and eicosapentaenoic acid were higher in shrimp fed with PS than the shrimp fed PK. Despite higher total fatty acid contents in hepatopancreas than in oocyte for the both treatments, the esensial fatty acid arachidonic, docosahexaenoic, and eicosapentaenoic acid were higher in oocyte than in hepatopancreas of the shrimp. This suggested that these three types of PUFA played important role for oocyte development for female reproduction. Supplementation of vitamin $\mathrm{C}$ and $\mathrm{E}$ in the test diet had an effect on increasing PUFA content in hepatopancreas and oocytes of tiger shrimp.
\end{abstract}

Keywords: Fatty acid profile; gonada; hepatopancreas; tiger shrimp; vitamin C and E.

\section{Introduction}

An effort to develop artificial diet to support shrimp broodstock production from aquaculture, appropriate nutrient specification should be determined for prematured phase (size about $40 \mathrm{~g}$ ) (Hoa, 2009). At this phase, reproductive organs of the tiger shrimp start to develop and become mature at the late phase of maturation. Several information on the nutrient specification of tiger shrimp in the early phase of reproduction have been reported. Doses and types of carotenoids (astaxanthine of $0.125 \%$, cantaxanthineof $0.068 \%$ and carotenoids from Spirulina at level of $0.3 \%$ ) was found to play an important role in increasing the number of broodstock to get mature which was $86.75 \%$ in female and $82.3 \%$ in male (Laining et al., 2016a). The total carotenoid level also increased in oocytes and hepatopancreas which were 554.6 and $558.1 \mu \mathrm{g} / \mathrm{g}$,respectively, higher than in mucles and carcass which were only 249.3 and $55.8 \mu \mathrm{g} / \mathrm{g}$, respectively. Enrichment of commercial diet with a combination of lipids using 5\% fish oil and 1\% olive oil tends to increase growth and increase total fatty acids in tiger shrimp meat and hepatopancreas compared to non-enriched commercial diet (Laining et al., 2016b).

Other nutrients that are also indispensable for the growth and reproduction process in fish and crustaceans are certain vitamins including vitamins $\mathrm{C}$ and $\mathrm{E}$. These 
vitamins can not be synthesized in the body, but obtained through the intake of food. Research on the kuruma shrimp (Marsupenaeus japonicus) showed that both vitamin $\mathrm{C}$ and vitamin $\mathrm{E}$ increased the hatching rate and larval metamorphosis from naupli to zoea as the doses of both vitamins increased from 0,500 and $1000 \mathrm{mg}$ ascorbic $\mathrm{acid} / \mathrm{kg}$ of diet and from 0,300 and $600 \mathrm{mg} \alpha$ tocopherol / $\mathrm{kg}$ of diet. Moreover, interactions between vitamin $\mathrm{C}$ and $\mathrm{E}$ were detected in both variables (Binh et al., 2012). Alava et al. (1993) applied concentrations of ascorbic acid (vitamin C) of $492 \mathrm{mg} / \mathrm{kg}$ and vitamin $\mathrm{E}$ of $482 \mathrm{mg} / \mathrm{kg}$ in diet for ovary development of Penaeus javonicus. While Laining et al. (2014) used vitamin C concentration of 200 $\mathrm{mg} / \mathrm{kg}$ and vitamin E concentration of 100 $\mathrm{mg} / \mathrm{kg}$ in diet of tiger shrimp broodstock. Despite its importance in reproductive process, excessive vitamin $\mathrm{E}$ in diet can also interfere with metabolic processes such as the onset of toxic reactions in the liver and slowing the fish growth (Halver, 2002).

Besides the effects on reproduction, vitamin $\mathrm{C}$ and vitamin $\mathrm{E}$ also play an important role in stimulating immune mechanisms in aquatic animals and as an antioxidant (Guillaume et al., 1999). Vitamins C and $\mathrm{E}$ synergistically protect cell membranes or precisely cell membrane lipids, liver, and adrenaline tissue from oxidation of harmful oxygen, lipid peroxide, and free radicals, as well as circulate the LDL (low density lipoprotein) (Combs, 1992). In cell membranes, these vitamins prevent the lipid oxidation, especially poly-unsaturated fatty acids (PUFAs), and protect the metabolic part that transforms energy fuels into adenosine triphosphate (ATP) in cell mitochondria.

In fish / shrimp breeding activities, condition and quality of PUFAs nutrition inherited from the broodstock is very important for pre-feeding embryos and larvae, where all the nutriens required for embryo and larvae development are supplied from the congenital yolk reserves (Harrison, 1990; Coman et al., 2011). The importance of fatty acids have well documented on development oocyte and survival rates of larvae such as metabolic energy sources, structural components in cellular membrane phospholipids, and bioactive molecular precursors (Sargent et al., 1999; Tocher, 2003), while hepatopancreas supplies nutrients for ovary development of tiger shrimp (Millamena and Pascual, 1990; Tseng et al., 2001). The growth of oocytes utilizing hepatopancreas lipid reserve had been reported on penaeid shrimps such as $P$. japonicus (Teshima and Kanazawa, 1983), and $P$. monodon (Millamena and Pascual, 1990). A decreasing of lipid content in hepatopancreas of $P$. monodon was associated to the increasing of the lipid profile of matured ovaries (Marsden et al., 2007). Therefore, this study was conducted to evaluate the effect of supplementing vitamin $\mathrm{C}$ and $\mathrm{E}$ in modifiedcommercial diet on fatty acid profile of hepatopancreas and gonad of cultured tiger shrimp, P. monodon.

\section{Materials and Methods}

\section{Test Animals}

Test animals used were cultured tiger shrimp with mean initial weight of $43.1 \pm 5.1$ $\mathrm{g}$ for females and $41.9 \pm 4.4 \mathrm{~g}$ for males (prematuration phase). The tiger shrimp were obtained from commercial farm in Pangkep District, South Sulawesi Province.

\section{Test Diets}

Two tested diets were evaluated for the pesent experiments. Both were modified diets using commercial diet specifically for tiger shrimp as the standard diet. As the treatments were: (i) modified-commercial diet supplemented with vitamin $\mathrm{C}$ at level of 500 $\mathrm{mg} / \mathrm{kg}$ and vitamin $\mathrm{E}$ at level of $300 \mathrm{mg} / \mathrm{kg}$ (PS), and (ii) modified-commercial diet without supplementation of both vitamin $\mathrm{C}$ and vitamin $\mathrm{E}(\mathrm{PK})$. The standard commercial diet used was a starter shrimp-feed with protein content of app. $45 \%$ and fat content of app 6\%. Its shape is crumble, therefore the test diets needed to be re-floured and repelleted based on the size of the prematurated shrimps. The modified commercial diet was based on the previous results on carotenoids supplementation (Laining et al., 2016a) and lipid addition (Laining et al., 2016b). Other modification was made by addition of fish meal, wheat flour and wheat gluten to adjust the diet to contain protein app. 45\%, $11 \%$ of lipid and $18.3 \mathrm{MJ} / \mathrm{kg}$ of gross energy, and water stability $\geq 4$ hours. The formulation and proximate composition of the test diets are 
presented in Table 1.

Table 1. Formulation and proximate composition of test diets (\% dry matter)

\begin{tabular}{|c|c|c|}
\hline Ingredients & PK & PS \\
\hline Commercial shrimp-feed & 67.4 & 67.4 \\
\hline Fish meal & 14.2 & 14.2 \\
\hline Wheat meal & 9.54 & 9.32 \\
\hline Wheat gluten & 4.8 & 4.8 \\
\hline Fish oil & 3 & 3 \\
\hline Olive oil & 1 & 1 \\
\hline Vitamin C (Stay C) & 0 & 0.2 \\
\hline Vitamin E & 0 & 0.02 \\
\hline Carophyll pink & 0.06 & 0.06 \\
\hline \multicolumn{3}{|l|}{ Proximate composition: } \\
\hline - Protein & 44.9 & 45.2 \\
\hline - Lipid & 10.5 & 10.7 \\
\hline - Crude fibre & 1.7 & 1.7 \\
\hline - Ash & 9.7 & 9.6 \\
\hline$-\mathrm{NFE}^{1)}$ & 33.2 & 32.8 \\
\hline - Gross energy $(\mathrm{MJ} / \mathrm{kg})^{2}$ & 18.2 & 18.3 \\
\hline - Vitamin $C(\mathrm{mg} / \mathrm{kg})$ & Not detected & 406.1 \\
\hline - Vitamin E $(\mathrm{mg} / \mathrm{kg})$ & 181.6 & 286.3 \\
\hline
\end{tabular}

\footnotetext{
1) Nitrogen-Free Extract

${ }^{2)}$ Calculated from the determined protein, lipid and NFE of the diet using gross energy conversion coefficients of 21.3; 39.5 and 17.2 MJ/kg, respectively (Cuzon and Guillaume, 1997).
}

\section{Condition of feeding trial}

\section{(i) Feeding trial held in concrete pond}

The selected shrimps were stocked into 2 of $1,000 \mathrm{~m}^{2}$ ponds. with a density of 100 shrimps/pond (0.1 shrimp. $\left./ \mathrm{m}^{2}\right)$ and ratio of male: female was $4: 6$. Feeding times was performed 4 times a day (at $07.00 ; 12.00$; 17.00; and 22.00 o'clock) at rate of $3 \%$ of shrimp biomass per day for 3 months of culture periode. To maintain the water quality within the optimal ranges, water was changed in every 3 days app. 10-20\%. Oxygen was supplied by using paddle wheel during night time.

\section{(ii) Feeding trial held inmaturation tank}

Afters shrimps reached maturation size (> $80 \mathrm{~g}$ for females and $>70 \mathrm{~g}$ for males), the shrimps were harvested from the pond, then transferred to 2 maturation concrete tanks in broodstock room of nucleus centre. The shrimps were stocked in $10 \mathrm{~m}^{3} /$ tank with 40 shrimps for PS and PK groups, respectively. Rasio of female and male for each group was 1:1 (20 females and males, respectively). During maturation process, the tested diets were fed to the shrimps as combination of
$50 \%$ pellet diet and $50 \%$ fresh squid at level of $3 \%$ (as dry basis) of total biomass per day.

\section{Data and Chemical Analysis}

Shrimp reaching gonad development stage of III-IV, were dissected for hepatopancreas and gonads samples. All those samples were freeze dried and kept at $-20^{\circ} \mathrm{C}$ until analyzis.

Proximate analysis of test diets were performed according to AOAC (1999) including moisture by oven drying at $105^{\circ} \mathrm{C}$ until constant weight, crude protein analyzed by micro-Kjeldahl, and lipid with gravimetrically determined by extracting chloroform: methanol in the Soxtherm, crude fiber by heating with alternating acid and base washing, and ash by combustion in a muffle furnace at $550^{\circ} \mathrm{C}$ for 24 hours. Vitamins $\mathrm{C}$ and E of test diets and fatty acid profile of hepatopancreas and oocyte were analyzed using High Performance Liquid Chromatography (HPLC) at the Saraswanti Indo Genetech Laboratory, Bogor. Data on fatty acids profile in hepatopancreas and oocyte of shrimp were analyzed descriptively. 


\section{Results}

Fatty acid profiles of oocytes and

PK diets were showed in Table 2. hepatopancreas of tiger shrimp fed test PS and

Table 2. Fatty acid profile (\% lipid) of oocytes and hepatopancreas of tiger shrimp broodstock fed with PS and PK test-diet

\begin{tabular}{|c|c|c|c|c|}
\hline \multirow{2}{*}{ Fatty acid profile } & \multicolumn{2}{|c|}{ Oocytes } & \multicolumn{2}{|c|}{ Hepatopancreas } \\
\hline & PK & PS & PK & PS \\
\hline C 6:0 & - & - & - & 0.0066 \\
\hline C 12:0 & 0.0186 & 0.0263 & - & 0.0249 \\
\hline C $14: 0$ & 0.1587 & 0.2427 & 0.6336 & 0.6424 \\
\hline C $14: 1$ & - & 0.0045 & - & - \\
\hline C $15: 0$ & 0.0449 & 0.0582 & 0.1897 & 0.2090 \\
\hline C $16: 0$ & 2.7803 & 3.9024 & 9.5062 & 9.5112 \\
\hline C $16: 1$ & 0.3681 & 0.5621 & 0.7453 & 0.7888 \\
\hline C $17: 0$ & 0.0921 & 0.1243 & 0.2213 & 0.2544 \\
\hline C $17: 1$ & 0.0517 & 0.0716 & 0.0960 & 0.0997 \\
\hline C 18:0 & 0.8479 & 1.2027 & 2.3848 & 2.3984 \\
\hline C $18: 1 n-9$ & 2.4699 & 3.6293 & 8.0789 & 7.8995 \\
\hline C $18: 2 n-6$ & 0.8195 & 1.2078 & 2.6746 & 3.2117 \\
\hline C $18: 3 n-3$ & 0.0345 & 0.0570 & 0.0831 & 0.1316 \\
\hline C 20:0 & 0.0469 & 0.0689 & 0.0962 & 0.1045 \\
\hline C 20:1 & 0.0609 & 0.0870 & 0.2730 & 0.3221 \\
\hline C $20: 2$ & 0.0638 & 0.0826 & 0.1520 & 0.1843 \\
\hline C $20: 3 n-3$ & 0.0101 & 0.0141 & - & 0.0186 \\
\hline C $20: 3 n-6$ & 0.0463 & 0.0694 & 0.0609 & 0.1051 \\
\hline C $20: 4 n-6$ & 0.5229 & 0.6820 & 0.2442 & 0.3989 \\
\hline C $20: 5 n-3$ & 0.5413 & 0.7420 & 0.1915 & 0.3203 \\
\hline C 21:0 & 0.0077 & 0.0113 & 0.0219 & 0.0292 \\
\hline C 22:0 & 0.0085 & 0.0138 & 0.0763 & 0.0717 \\
\hline C 22:1 & 0.0046 & 0.0062 & 0.0287 & 0.0379 \\
\hline C $22: 2$ & 0.0191 & 0.0284 & 0.0244 & 0.0509 \\
\hline C 22:6n-3 & 1.4812 & 1.8368 & 0.4620 & 0.7828 \\
\hline C 23:0 & - & - & 0.0357 & 0.0326 \\
\hline C 24:0 & 0.0039 & 0.0173 & 0.0541 & 0.0518 \\
\hline C 24:1n-9 & 0.013 & 0.0177 & 0.0355 & 0.0472 \\
\hline Total & 10.5164 & 14.7664 & 26.3699 & 27.7361 \\
\hline
\end{tabular}

Oocytes of tiger shrimp fed the PS diets had a relatively higher amount of total fatty acid $(14.7664 \%)$ from 26 identified fatty acids than the amount of total fatty acid $(10.5164 \%)$ from 25 identified fatty acids in the oocytes of tiger shrimp were fed the PK test diet. Similarly, hepatopancreas of shrimp fed with PS diet had a relatively higher amount of total fatty acid (27.7361\%) from 27 identified fatty acids than fed with PK diet. Total fatty acids content in the hepatopancreas is generally higher than in oocytes for the both treatmens.

Concentration of n-3, n- 6 and n-9 in oocytes was higher in shrimp fed PS diet than those fed PK diet as illustrated by Figure 1. In the hepatopancreas, n-3 and n-6 fatty acid levels were higher in shrimp fed PS diet than those fed PK diet, but n-9 fatty acid contents were relatively similar between those fed PS and PK diets. Furthermore, the pattern of n-3, n-6 and n-9 fatty acid contents were different between oocytes and hepatopancreasin which the content of $n-6$ fatty acids in the hepatopancreas was higher than its n-3 fatty acid content, while the oocytes $n-6$ fatty acid level was lower than n-3 fatty acid content.

In regard to poly-unsaturated fatty acids (PUFAs), particularly arachidonic (ARA), docosahexaenoic (DHA), and eicosapentaenoic (EPA) content, their patterns are presented in Figure 2. These three fatty acid were higher in shrimp fed with PS diet than shrimp fed PK diet. In both groups, it was observed that ARA, EPA and DHA content was higher in oocytes than in hepatopancreas. Based on the results of calculation, the ratio of 
DHA / EPA of fatty acid contents in oocytes of shrimp fed PS diet was 2.49, which is not much different from shrimp fed PK diet which was 2.74. Likewise, the ratio of DHA / EPA of fatty acid contents in the hepatopancreas was relatively similar between shrimp fed PS diet and shrimp fed PK diet which were 2.43 and 2.42 , respectively.

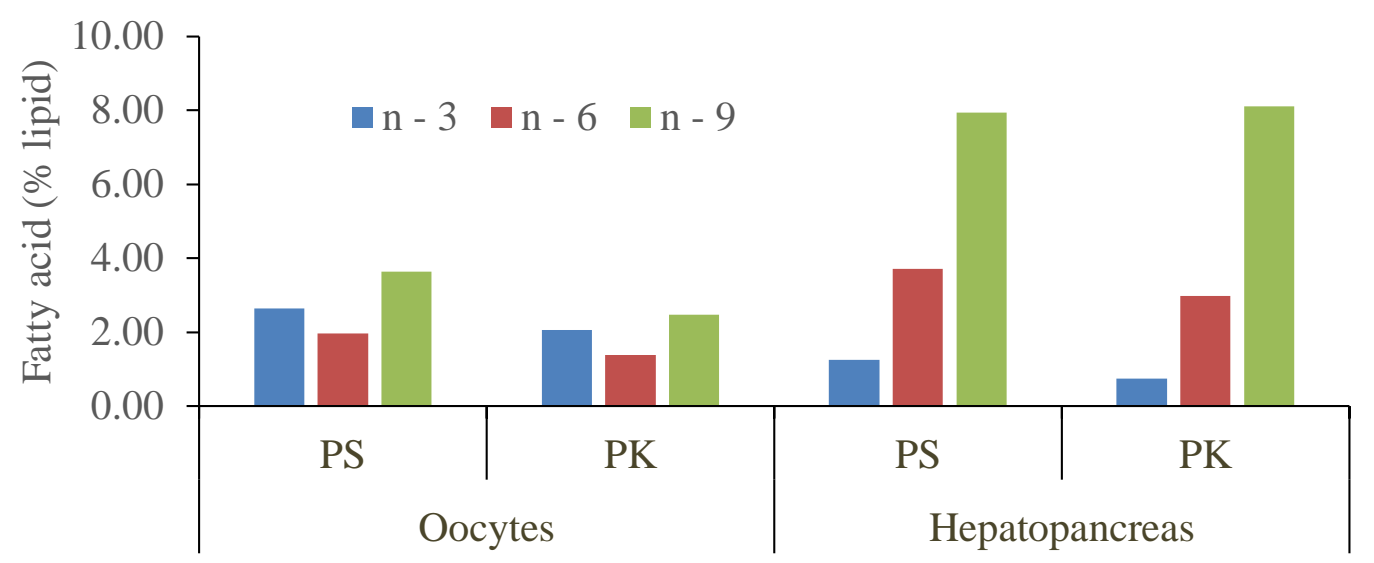

Figure 1. Fatty acid content of n-3, n-6 and n-9 in oocytes and hepatopancreas of tiger shrimp broodstock fed with PS and PK test-diet.

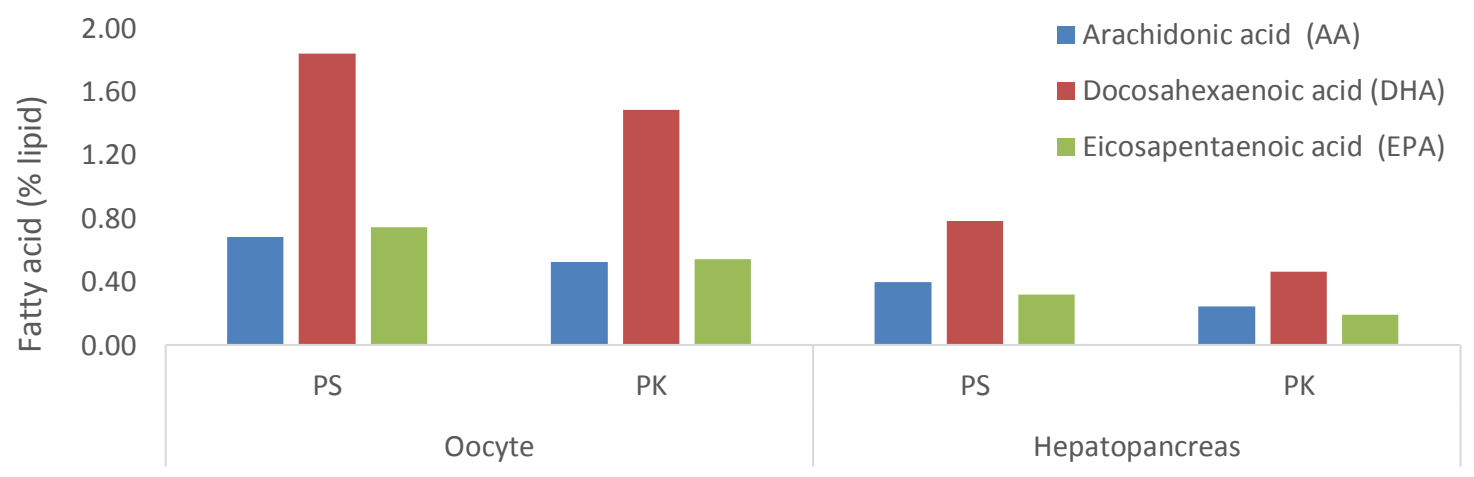

Figure 2. Poly unsaturated fatty acids (PUFAs) in oocytes and hepatopancreas of tiger shrimp broodstock fed with PS and PK test-diet.

\section{Discussion}

Some researchers have reported that the administration of vitamin $\mathrm{C}$ and $\mathrm{E}$ in the diet may have an effect on the profile of fatty acids in fish body tissues (Chien and Hwang, 2001;Gao et al.,2013;2014). The higher content of total fatty acid in oocytes and hepatopancreas tissues of tiger shrimp fed PS test-diet compared to the shrimp fed PK testdiet, suggested that supplementation of vitamin $\mathrm{C}$ and vitamin $\mathrm{E}$ in test diet affects the profile of fatty acids in oocytes and hepatopancreas of tiger shrimp. Fatty acids are one of the most important nutrients needed by heterotrophic organisms such as tiger shri- $\mathrm{mp}$, because they have many functions such as energy sources, solvents of vitamins such as $\mathrm{A}, \mathrm{D}, \mathrm{E}$, and $\mathrm{K}$ as well as some other metabolic functions in the body. In reproduction process of penaeid shrimp, fatty acids are one of required nutrients during vitellogenesis since fatty acids increase fecundity, fertilization and hatching rates of egg (Xu et al., 1994; Wouters et al., 2001; Racotta et al., 2003). Fatty acids are distinguished into saturated fatty acids (having only a single bond between the constituent carbon atoms) and unsaturated fatty acids (having at least one double bond between the constituent carbon atoms) (Murray et al., 1996). Some fatty acids are essential for 
marine fish and crustaceans including for tiger shrimp because they can not or are limited in their ability to biosynthesize in their body especially the unsaturated fatty acids of EPA, DHA and ARA groups (Sargent et al., 2002).

This present study also found that the content of n-3 and n- 6 fatty acids were higher in oocytes and hepatopancreas of tiger shrimp fed PS test diet compared to tiger shrimp fed PK test diet. This implies that the supplementation of vitamin $\mathrm{C}$ and $\mathrm{E}$ in the test diet had an effect on increasing the content of these fatty acids in the two important tissues of tiger shrimp. Hepatopancreas is the main tissue in the shrimp body that plays role in the processing of food (nutrient) after being digested and absorbed for further distribution to all tissues that need it. High concentration of fatty acid in oocytes particularly in vitellogenin (glicolipoprotein) contributes in development of oocyte and larvae. In the same time, fatty acid content is also high in the hepatopancreas, where vitellogenin takes place. According to Quackenbush (1989), vitellogenin in shrimp is produced partly in hepatopancreas and ovary. Furthermore, Diwan et al. (2009), also concluded that in tiger shrimp, most of the vitellogenin is produced in the ovaries and a small portion is supplemented from outside tissue. While Chang et al. (1994) reported that vitellogenin in tiger shrimp is produced outside the ovary tissue. Some researchers have reported that several sites of vitellogenesis in decapoda crustaceans namely the hepatopancreas, haemocytes of the haemolymph, and subepidermal adipose tissue of maturing crustaceans (Quinitio et al., 1989 \& 1990; Chang et al. 1993; Chang and Shih, 1995). Therefore, the nutrient content in the hepatopancreas can provide an overview of the nutrients eaten and metabolized by shrimp. Bai and Lee (1998) found an increase of linoleic, linolenic and arachidonic liver content in juvenile Korean rockfish associated with increased vitamin $\mathrm{E}$ at $120 \mathrm{mg} / \mathrm{kg}$ of diet. Tocher et al. (2002) also found an increase in fatty acid content of EPA, DHA, total omega-3 PUFA and total PUFA in liver of halibut (Hippoglossus hippoglossus) fed diet with vitamin $\mathrm{E}$ supplementation than in liver of halibut fed diet without supplementation. The presence of vitamin $\mathrm{E}$ in certain tissues will protect PUFA from oxidative damage. Therefore, PUFA content should be combined with vitamin $\mathrm{E}$ to protect against physiological oxidation (Sargent et al., 1997). Izquierdo and Fernandez-Palacios (1997) reported that vitamin E and PUFA levels in the tissues were closely interconnected. Both nutrients had a synergistic effect on non-specific immune responses on fish such as Japanese flounder (Paralychthis olivaceous) (Wang et al., 2006). The PUFA / $\alpha$-tocophero ratio becomes very important in determining tissue deficits against fatty acid peroxidation (Stephan et al., 1995). While Ji et al. (2003) reported that vitamin C supplementation in the diet tended to decrease the liver fat content of red sea bream (Pagrus major) and black sea bream (Acanthopagrus schlegeli), but not with vitamin $\mathrm{E}$ supplementation. It was further explained that the mechanism of decreasing the lipid content caused by vitamin $\mathrm{C}$ triggers the process of lipolysis in the fish.

Vitamin $\mathrm{C}$ and $\mathrm{E}$ synergistically prevent low-density lipoprotein (LDL) oxidized, functioning as an antioxidant, primarily in cell membranes or precisely on cell membrane lipids, LDL circulation, liver, and adrenaline tissue (Combs, 1992). As an antioxidant, vitamin $\mathrm{E}$ is a major defense against harmful oxygen, lipid peroxide, and free radicals and stops the chain reaction of free radicals. In cell membranes, vitamin $\mathrm{E}$ prevents lipid oxidation, especially poly unsaturated fatty acids (PUFAs), protecting the metabolic part that will transform energy fuels into adenosine triphosphate (ATP) in cell mitochondria. In body lipid tissues, antioxidants from vitamin $\mathrm{E}$ invade lipid peroxide which is the result of a reaction between lipids and free radicals. The antioxidant properties of vitamin $\mathrm{E}$ are a defense against free radicals. Free radicals will attack cell growth, including deoxy nucleic acid (DNA) and PUFA. When free radicals react with PUFA, free radicals will damage the structure and function of cell membrane, nucleic acid, and electrodense region protein (Combs, 1992).

Oocyte is an egg that will be spawned to hatch into shrimp larvae, and the nutrient content of the oocytes can be an illustration of the quality of the larvae that will be produced. Therefore, when observed and analyzed further, it appears that the fatty acid content of n-3 and n-6 (PUFAs) in particular the ARA, DHA, and EPA content were higher in oocytes than in hepatopancreas. This suggested that 
these three types of PUFAs played important role for oocyte development for female reproduction. The essential fatty acids n-3 HUFA (EPA, DHA) and ARA are often the limiting factors in the early life of marine fish/crustacean larvae because the need for this nutrients for larvae is quite high while this nutrient content of early feed of larvae is often very low. Several studies have shown that low survival of marine fish larvae was partly due to the lack of n-3 HUFA and ARA content in their diet (Reitan et al., 1997). Marine fish generally contains n-3 HUFA in the body of about $23.3 \%$, with the composition of DHA about $11.3 \%$ and EPA about $8.1 \%$ of total lipid in the body (Hepher, 1990). Therefore, to obtain high growth and survival, marine fish must have sufficient n-3 HUFA in the diet (Sargent et al., 1997).

The ratio of DHA / EPA in fatty acid content in oocytes to shrimp fed PS diet and those fed PK diet was not much different. Likewise, the ratio of DHA / EPA fatty acid content in the hepatopancreas was relatively similar between shrimp fed PS diet and shrimp fed PK diet. This implies that the supplementation of vitamin $\mathrm{C}$ and $\mathrm{E}$ in the diet test did not have effect on the ratio of these fatty acids in the two important tissues of tiger shrimp. Coman et al. (2011) reported that domesticated tiger shrimp fed diet with ARA fatty acid supplementation of $0.75 \%$ had a ratio of DHA / EPA in eggs (oocytes) of 1.79 and provided better reproductive performances compared to tiger shrimp fed control diet without ARA supplemented with a DHA / EPA content ratio in eggs of 1.68. This shows that the high DHA / EPA ratio in oocyte tends to produce good reproductive performance of tiger shrimp.

Essential fatty acid is also a component of phospholipids in biomembranes. In general the physiological and cellular functions of these fatty acids are (i) maintaining the structural and functional integrity of cell membranes and (ii) as precursors for the formation of group 3 eicosanoid 3 ie. prostaglanding series-3, prostacyclinase- 3 , and 5-series leukotrine, which is a physiologically active compound (Sargent et al., 1997). The presence of a balanced n-3 HUFA in cell membranes can maintain and improve membrane fluidity levels, so that cell metabolism can proceed normally. This occurs because cell membrane phospholipids, especially the phosphatidylserin and phosphatidylglycerol types can affect the activity of $\mathrm{Na}+$ / $\mathrm{Ka}+$ ATPase enzymes found in cell membranes (Hepher, 1990). The n-3 HUFA compound has a very low freezing point, thereby increasing the flexibility and permeability of cell membranes ( $\mathrm{Li}$ et al., 1994). The high flexibility and permissiveness of cell membranes will increase the activity of ion transporting processes into cells and is essential for the process of adaptation and osmoregulation of fish.

Embryos and pre-feeding larvae of some marine fish (including shrimp larvae) are lecitotrophic, since their nutritional needs are only supplied from the congenital yolk reserves (Harrison, 1990). Therefore, the condition and quality of the broodstock nutrient has been shown to affect the reproductive performance and quality of the larvae produced. Based on the content of fatty acids in oocytes and hepatopancreas, it can be predicted that tiger shrimp fed with PS diet can likely produce larvae with a better quality than the larvae produced by tiger shrimp fed PK diet.

\section{Conclusion}

Total fatty acid contents of oocytes and hepatopancreas were higher in the tiger shrimp fed PS test diet compared to tiger shrimp fed PK test diet. ARA, DHA, and EPA had higher content in the tiger shrimp fed PS diet compared to the tiger shrimp fed PK test diet. Also the PUFAs were found higher content in oocyte than in hepatopancreas of the tiger shrimp. Supplementation of vitamin C and E in the modified commercial diet had an effect on increasing PUFA content in hepatopancreas and oocytes of tiger shrimp.

\section{Acknowledgement}

This study was supported by Indonesian Government through DIPA-APBN 2017 of Research Institute for Coastal Aquaculture and Fisheries Extension (RICAFE). The authors gratefully thank to the technicians and analist of the Laboratory of Nutrition and Feeding Technology of RICAFE (Munawir, Tamsil, Ramadan, Umar, Wendy, and Rosni) for all their assistances both for laboratory work and feeding trial in the field. 


\section{References}

AOAC (Association of Official Analytical Chemists). 1999. Official Methods of Analysis, $16^{\text {th }}$ edn. Association of Official Analytical Chemists International, Gaithersberg, Maryland, USA.1141 pp.

Bai, S.C and K.J. Lee. 1998. Different levels of dietary DL-a-tocophery affect the vitamin status of juvenile Korean rockfish, Sebastes schlegeli. Aquaculture, 168(1-4): 415-444.

Binh, T., N., S. Koshio, K. Sakiyama, S. Harakawa, J. Gao, R.E. Mamauag, M. Ishikawa, and S. Yokoyama. 2012. Effects of dietary vitamin $\mathrm{C}$ and $\mathrm{E}$ and their interaction on reproductive performance, larval quality and tissue vitamin contents in kuruma shrimp, Marsupenaeus japonicus Bate. Aquaculture, 334-337: 73-81.

Cavalli, R.O., F.M.M. Batista, P. Lavens, P. Sorgeloos, H.J. Nelis, and A.P. De Leenheer. 2003. Effect of dietary supplementation of vitamin $\mathrm{C}$ and $\mathrm{E}$ on maternal performance and larval quality of the prawn Macrobrachium rosenbergii. Aquaculture, 227 (1-4): 131-146.

Chang, C.F., F-Y. Lee, and T.H. Hong. 1994. Purification and characterization of the female specific protein in mature female haemolymph of the prawn Penaeus monodon. Invertebrate Reproduction and Development, 25(3): 185-191.

Chang, C.F., F-Y. Lee, and Y.S. Huang. 1993. Purification and characterization of vitelline from the mature ovaries of prawn, Penaeus monodon. Comparative Biochemistry and Physiology, 105B (2): 409-414.

Chang, C.F. and Shih, T.W. 1995. Reproductive cycle of ovarian development and vitellogenin profile in freshwater prawn, M. rosenbergii. Invertebrate Reproduction and Development, 27(1):11-20.

Chien, L.T. and D.F. Hwang. 2001. Effects of thermal stess and vitamin $\mathrm{C}$ on lipid peroxidation and fatty acid composition in the liver of thorn fish Terapon jarbua. Comparative Biochemistry and Physiology, 128B: 91-97.

Coman, G.J., S.J. Arnold, M. Barclay, and D.M. Smith. 2011. Effect of arachidonic acid supplementation on reproductive performance of tank-domesticated Penaeus monodon. Aquaculture Nutrition 17, 141-151.

Combs, G.F.Jr. 1992. The Vitamin: Fundamental aspects in nutrition and health. Academic Press, New York, 525 p.

Cuzon, G. and J. Guillaume. 1997. Energy and protein: energy ratio. In Crustacean Nutrition - Advances in Word Aquaculture VI (eds. By L. D'Abraamo, D. Conklin \& D Akiyama).
Pp. 51-70. World Aquaculture Society, Los Angeles, USA.

Diwan, A.D., S. Joseph, and S. Ayyappan. 2009. Physiology of Reproduction, Breeding and Culture of Tiger Shrimp Penaeus monodon (Fabricius). Narendera Publishing House. Delhi. India, 292 pp.

Gao, J., S. Koshio, M. Ishikawa, S. Yokoyama, N. Daisuke, and T.J. Ren. 2013. Interactive effects of vitamin $\mathrm{C}$ and $\mathrm{E}$ supplementation on growth performance, fatty acid composition and lipid peroxidation of sea cucumber, Apostichopus japonicus, fed dietary oxidized fish oil. The Journal of World Aquaculture Society. 44: 536-546.

Gao, J., S. Koshio, M. Ishikawa, S. Yokoyama, and R.E.P. Mamauag. 2014. Interactive effects of vitamin $C$ and $E$ supplementation on growth performance, fatty acid composition and reduction of oxidative stress in juvenile Japanese flounder Paralichthys olivaceus fed dietary oxidized fish oil. Aquaculture, 422423: 84-90.

Guillaume, J., S. Kaushik, P. Bergot, and R. Metailler. 1999. Nutrition and Feeding of Fish and Crustaceans. INRA, IFRAMER, Springer, UK. 408 p.

Halver, J.E. 2002. The vitamins. In: Halver, J.E. and R.W. Hardy (Editors). Fish Nutrition. New York: Academic Press, page. 453-504.

Harrison, K.E. 1990. The role of nutrition in maturation, reproduction, and embryonic development of decapod crustaceans. Journal of Shellfish Research, 9: 1-28.

Hepher, B. 1990. Nutrition of Pond Fishes. Cambridge University Pres, New York. 388p.

Hoa, N.D. 2009. Domestication of black tiger shrimp (Penaeus monodon) in recirculation systems in Vietnam. $\mathrm{PhD}$ thesis, Ghent University, Belgium.

Izquierdo, M, and H. Fernandez-Palacios. 1997. Nutritional requirement of marine fish larvae and broodstock. Cahes Option Mediterranean, 22: 243-264.

Ji, H., Om, AD., T. Yoshimatsu, M. Hayashi, T. Umino, H. Nakagawa, M. Asano, and A. Nakagawa. 2003. Effect of dietary vitamins $\mathrm{C}$ and $\mathrm{E}$ fortification on lipid metabolism in red sea bream Pagrus major and black sea bream Acanthopagrus schlegeli. Fisheries Science, 69:1001-1009.

Laining, A., Rachmansyah, Usman, N.N. Palinggi, Kamaruddin, S. Lante, I. Trismawanti,W. Santiadjinaata, Tamsil, Rosni, Umar and Ramadan. 2016b. Feed formulation for prematuration tiger shrimp (in Indonesia). Annual Report, Research Institute for Coastal Aquaculture, Maros, 33 pp. .

Laining, A., Usman, and I. Trismawanti. 2016a. 
Dietary carotenoid in prematuration diet enhanced gonadal maturation and total carotenoid in several tissues of pond reared black tiger shrimp (Penaeus monodon). Book of Abstract of Asian Pacific Aquaculture 2016, 26-29 April 2016, Surabaya, Indonesia.

Laining, A., Usman, and R. Syah. 2014. The use of seaworm meal in maturation diet as partial substitution on fresh diet for pond reared tiger shrimp broodstock. Indonesian Aquaculture Journal, 9(2): 123-132.

Li, M.H., D.J. Wise, M.R. Johnson, and E.H. Robinson. 1994. Dietary manhaden oil reduce resistence of channel catfish (Ichtalurus punctatus) to Edwardsiella ictaluri. Aquaculture, 128:335-344.

Marsden, G., P. Mather, and N. Richardson. 2007. Captivity, ablation and starvation on the prawn Penaeus monodon affects protein and lipid content in ovary and hepatopancreas tissues. Aquaculture, 271: 507-515.

Murray, R.K., D.K. Granner, P.A. Mayes, and V.W. Rodwell. 1996. Harper's Biochemistry $24^{\text {th }}$ Edition. Appleton \& Lange, Stamford, CT. 868 pp.

Millamena, O.M. and F.P. Pascual. 1990. Tissue lipid content and fatty acid composition of Penaeus monodon Fabricius broodstock from the wild. The Journal of World Aquaculture Society, 21(2): 116-121.

Quackenbush, L.S. 1989. Vitellogenesis in the shrimp, Penaeus vannamei in vitro studies of the isolated hepatopancreas and ovary. Comparative Biochemistry and Physiology, 94B: 253-261.

Quinitio, E.T., A. Hara, K. Yamauchi, T. Mizushima, and A. Fuji. 1989. Identification and characterization of vitellin in a hermaphrodite shrimp, Pandalus kessleri. Comparative Biochemistry and Physiology, 94B (3): 445-451.

Quinitio, E.T., A. Hara, K. Yamauchi, and A. Fuji. 1990. Isolation and characterization of vitellin from the ovary of Penaeus monodon. Invertebrate Reproduction and Development, 17(3): 221-227.

Racotta, I.S., E. Palacios, and A.M. Ibarra. 2003. Shrimp larval quality in relation to broodstock condition. Aquaculture, 227: 107130.

Reitan, K.I., J.R. Rainuzzo, G. Oie, and Y. Olsen. 1997. A review of the nutritional effects of algae in marine fish larvae. Aquaculture, 155:207-221.

Sargent, J.R., L.A. McEvoy, L.A., and J.G. Bell. 1997. Requirements, presentation and sources of polyunsaturated fatty acids in marine fish larval feeds. Aquaculture, 155:117-127.

Sargent, J.R., J.G. Bell, L.A. McEvoy, D.R. Tocher, and A. Estevez. 1999. Recent developments in the essential fatty acid nutrition of fish. Aquaculture, 177: 191-199.

Sargent, J.R., D.R. Tocher, and J.D. Bell. 2002. The Lipid. In: Halver, J.E \&R.W. Hardy, (Eds). Fish Nutrition. New York: Academic Press, pp. 181-257.

Stephan, G., J. Guillaume, and F. Lamour. 1995. Lipid peroxidation in turbot (Scophthalmus maximus) tissue: effect of dietary vitamin $\mathrm{E}$ and dietary n-6 or n-3 polyunsaturated. Aquaculture, 130: 251-268.

Teshima, S. and A. Kanazawa. 1983. Variation in lipid composition during the ovarian maturation of the prawn. Bulletin of the Japanese Society of Scientific Fisheries, 49(6): 957-962

Tseng, D.Y, Y-N. Chen, G-H. Kou, C-F. Lo, and C-M. Kou. 2001. Hepatopancreas is the extraovarian site vitellogenin synthesis in black tiger shrimp, Penaeus monodon. Comparative Biochemistry Physiology, 129A: 909-917.

Tocher, D.R., G. Mourente, A. Van der Eecken, J.O. Evjemo, E. Diaz, J.G. Bell, I. Geurden,P. Lavens, and Y. Olsen. 2002. Effects of dietary vitamin $\mathrm{E}$ on antioxidant defence mechanisms of juvenile turbot (Scophthalmus maximus L.), halibut (Hippoglossus hippoglossus L.) and sea bream (Sparus auratus L.). Aquaculture Nutrition, 8: 195-207.

Tocher, D.R. 2003. Metabolism and functions of lipids and fatty acids in teleost fish. Review in Fisheries Science, 11:107-184.

Wang, Z., K. Mai, Z.Liufu, H. Ma, W. Xu, Q. Ai, W. Zhang, B. Tan, and X. Wang. 2006. Effect of hight dietary intake vitamin $\mathrm{C}$ and n-3 HUFA on immune response and resistence to Edwardsiella tarda challenge in Japanese flounder (Paralichhthys olivaceus, Temminck). Aquaculture, 37: 618692.

Wouters, R., P. Lavens, J. Nieto, and P. Sorgeloos. 2001. Penaeid shrimp broodstock nutrition: an update review on research and development. Aquaculture, 202: 1-21.

Xu, X.L., J.D. Castell, and R.K. O'Dor. 1994. Influence of dietary lipid sources on fecundity, egg hatchabiity, and fatty acid composition of Chinese prawn (Penaeus chinensis) broodstock. Aquaculture, 119: 359370 . 